\title{
THE TITRATION OF VACCINIAL NEUTRALIZING ANTIBODY ON CHORIO-ALLANTOIC MEMBRANES
}

\author{
By E. A. BOULTER \\ Microbiological Research Establishment, Porton, near Salisbury, Wiltshire
}

(With 7 Figures in the Text)

\section{INTRODUCTION}

Ever since Sternberg (1892) showed that the addition of immune serum to a suspension of vaccinia virus rendered the latter non-infectious, the neutralization test has been one of the most useful techniques available for the study of virus diseases. The fields to which it has been applied include those of epidemiology, diagnosis, the assay of vaccines and the identification of virus strains. If, as in many of the above cases, the only information sought is whether or not an antiserum has any effect on a virus suspension, the precision of the test is relatively unimportant. When, however, it is necessary to compare the activities of different antisera, precision becomes of fundamental importance.

The accuracy of any neutralization test is dependent on the accuracy with which the virus can be titrated, both in the presence and absence of antibody. Since vaccinia can be titrated more accurately on the chorio-allantoic membrane (CAM) of chick embryos than on rabbit skin, it would be expected that a neutralization test carried out on the CAM would give a more accurate result than one done on rabbit skin. However, despite the frequent use of the CAM for neutralization tests, the most accurate method available for the titration of vaccinial antiserum still appears to be that of Parker (1939), in which rabbits are used.

This paper describes an attempt to analyse various factors which affect the accuracy of titrating neutralizing antibody on the CAM. The method finally used is essentially that employed by Keogh (1936), Burnet, Keogh \& Lush (1937) and by Downie \& McCarthy (1950) in their analysis of the antigenic relationships between members of the pox-group of viruses. However, these authors gave few details of their technique and the advantages of the method appear to have been overlooked by other workers.

\section{MATERIALS}

Virus. A strain of vaccinia virus, which had been propagated for many years on rabbit skin, was kindly supplied by Prof. A. W. Downie.

Sera. Either rabbit convalescent or human post-vaccination sera were used. They were stored at $-20^{\circ} \mathrm{C}$. after heating at $56^{\circ} \mathrm{C}$. for $30 \mathrm{~min}$.

Eggs. Two types of eggs have been used, each giving similar results. They were obtained either commercially, from a Rhode Island/Light Sussex cross, or from White Leghorns raised at the Ministry of Supply Establishment, Allington Farm, Porton. The chorio-allantoic membranes were dropped, in the manner described 
by Westwood, Phipps \& Boulter (1957), approximately $2 \frac{1}{2}$ hr. before inoculation; this corresponded with the period of maximum sensitivity of the membranes shown by these authors to occur after creation of an artificial air-sac. All eggs were used after 12 days' incubation and harvested after a further 2 days' incubation. The inocula were introduced in $0 \cdot 1 \mathrm{ml}$. volumes.

\section{Diluents}

Skimmed milk. Fresh milk was allowed to stand in the refrigerator until separation of the cream had occurred. The latter was then siphoned off and the skimmed milk steamed for $30 \mathrm{~min}$. in separating funnels. After standing overnight to allow any remaining cream to separate, the milk was run off from below into bottles and sterilized by steaming for $30 \mathrm{~min}$. on three successive days. The $\mathrm{pH}$ was $6 \cdot 6$.

Tryptic meat broth. A tryptic digest of lean beef, diluted to contain $500 \mathrm{mg}$. of nitrogen per $100 \mathrm{ml}$. and having a $\mathrm{pH}$ of $7 \cdot 6$, was bottled and autoclaved at $10 \mathrm{lb}$. for $15 \mathrm{~min}$.

Peptone water. A $1 \%$ solution of Evan's Bacteriological Peptone was prepared in distilled water, adjusted to $\mathrm{pH} \mathrm{7.6}$ and autoclaved at $10 \mathrm{lb}$. for $15 \mathrm{~min}$.

Bovine serum albumin. Armour's Fraction $V$ was dissolved to a concentration of $0.2 \%$ in $0.004 \mathrm{M}$ Mcllvaine buffer and filtered through a Seitz filter. The final $\mathrm{pH}$ was $7 \cdot 16$.

Phosphate buffer. Solutions of sodium dihydrogen and disodium hydrogen phosphates were mixed to give an isotonic fluid of $\mathrm{pH} 7.2$ and $0.122 \mathrm{M}$ concentration. It was sterilized by autoclaving.

Citric acid/phosphate buffer. This was a $0.004 \mathrm{M} \mathrm{McIlvaine} \mathrm{buffer} \mathrm{of} \mathrm{pH} 7.2$ which was sterilized by autoclaving.

To all the above diluents penicillin and streptomycin were added to give a final concentration of 500 units and $50 \mu \mathrm{g} . / \mathrm{ml}$., respectively. They were used for the dilution of both antiserum and virus.

\section{EXPERIMENTAL}

Temperature of incubation

There is considerable lack of uniformity in the literature regarding the temperature at which serum-virus mixtures should be incubated before inoculation upon the CAM. They have ranged from $0^{\circ} \mathrm{C}$. (Burnet \& Lush, 1939), through $4^{\circ} \mathrm{C}$. (Briody, Ledinko \& Stannard, 1951) and room temperature (Downie \& McCarthy, 1950) to $37^{\circ}$ C. (Jawetz \& Coleman, 1952).

It has been shown by Dulbecco, Vogt \& Strickland (1956) that the rate of neutralization is proportional to the temperature. However, the higher the temperature used the greater is the risk of thermal inactivation occurring and masking the specific action of the antiserum. It was arbitrarily decided, therefore, to use $37^{\circ} \mathrm{C}$. as representing a temperature, readily available in most laboratories, at which neutralization would proceed rapidly and thermal inactivation would be negligible. 


\section{Stability of the virus at $37^{\circ} \mathrm{C}$. in various diluents}

The protective action of serum upon virus suspensions is well known. In a serum titration this protection would decrease progressively as the serum dilution increased. A search was therefore made for a diluent in which the virus would remain stable at $37^{\circ} \mathrm{C}$., even in the complete absence of serum.

For this purpose $0.5 \mathrm{ml}$. of a virus suspension was added to $49.5 \mathrm{ml}$. of the diluent under test to give a final concentration of about 500-700 pock-forming units (P.F.U.) per ml. and $0.1 \mathrm{ml}$. vol. of the mixtures were then inoculated into groups of seven to ten eggs, both before and after incubation for $2 \mathrm{hr}$. at $37^{\circ} \mathrm{C}$. The percentage survivals of virus under these conditions are given in Table 1. It should be pointed out that results in any one column do not imply that the tests were done on the same day; the supply of eggs was not sufficient for all diluents to be tested simultaneously.

Table 1. Percentage survival of vaccinia virus in various diluents after $2 \mathrm{hr}$. incubation at $37^{\circ} \mathrm{C}$.

\begin{tabular}{|c|c|c|c|c|c|c|c|}
\hline \multirow[b]{2}{*}{ Diluent } & \multicolumn{6}{|c|}{ Experiment number } & \multirow{2}{*}{$\begin{array}{l}\text { Mean \% } \\
\text { survival }\end{array}$} \\
\hline & 1 & 2 & 3 & 4 & 5 & 6 & \\
\hline Bovine serum albumin $0.2 \%$ & 120 & 80 & 89 & 132 & 95 & 105 & 104 \\
\hline Skimmed milk & 83 & 93 & 91 & 92 & 80 & 114 & 92 \\
\hline McIlvaine buffer $0.004 \mathrm{M}$ & 79 & 91 & 68 & 67 & 76 & 81 & 77 \\
\hline Tryptic meat broth & 50 & 57 & 69 & 101 & 84 & 85 & 74 \\
\hline Peptone water $1 \%$ & 67 & 69 & 58 & 59 & 35 & 20 & 51 \\
\hline Phosphate buffer & 6 & 70 & 45 & 17 & 61 & 16 & 36 \\
\hline
\end{tabular}

Of the six reagents tested, skimmed milk and bovine serum albumin provided the best protection for the virus. The latter, however, occasionally gave some unexpected results in which the titre of the virus apparently increased after incubation; furthermore, whenever both reagents were tested simultaneously the serum albumin gave slightly but consistently lower titres than the skimmed milk. For these reasons skimmed milk was preferred. Recent experiments, unconnected with this work, have shown that virus suspensions suffer no fall in titre over a period of $24 \mathrm{hr}$. when kept at $37^{\circ} \mathrm{C}$. in $10 \%$ skimmed milk in McIlvaine buffer. Even after 5 days of such treatment the fall in titre is just over $50 \%$. Although the experiments reported below were carried out with undiluted skimmed milk, a $10 \%$ suspension appears to be just as satisfactory. In fact, the latter has been used routinely in this laboratory during the past few months with excellent results.

\section{Preparation and storage of standard virus suspensions}

The early experiments in this work were done with crude dermal pulp. When, however, the merits of skimmed milk as a suspending medium became apparent it was decided to prepare purified suspensions in this fluid and store them in small amounts in order that virus suspensions of predictable titre could consistently be obtained. 
Accordingly, the crude pulp was clarified by light centrifugation and the virus deposited at 10,000 $\mathrm{g}$ for $30 \mathrm{~min}$. on a 'Phywe' refrigerated centrifuge. The deposit was taken up in skimmed milk, homogenized on a vertical shaker and again clarified by light centrifugation. The whole process was repeated and the final supernatant fluid stored at $-60^{\circ} \mathrm{C}$. in approximately $5 \mathrm{ml}$. vol. At intervals a bottle was thawed, diluted tenfold in skimmed milk and rebottled in accurately measured $0.5 \mathrm{ml}$. volumes which were again stored at $-60^{\circ} \mathrm{C}$. For use, $4.5 \mathrm{ml}$. of skimmed milk was added to the thawed contents of one of these bottles and serial dilutions continued to give the desired concentration of virus.

The titres obtained from fifteen consecutively used samples from a stock of purified virus are given in Table 2. The period elapsing between the titrations of the first and the last sample was over 5 months. It will be seen that no loss of titre occurred over this period and that the variation between samples was small.

Table 2. Titres of consecutively used samples of stock virus

$\begin{array}{cccc}\text { Sample } & \begin{array}{c}\text { Titre } \times 10^{-8} \\ \text { per ml. }\end{array} & \begin{array}{c}\text { Titre } \times 10^{-8} \\ \text { per ml. }\end{array} \\ 1 & 0.83 & 9 & 1.60 \\ 2 & 1.02 & 10 & 1.59 \\ 3 & 1.50 & 11 & 0.94 \\ 4 & 1.44 & 12 & 1.65 \\ 5 & 1.04 & 13 & 1.06 \\ 6 & 0.93 & 14 & 0.96 \\ 7 & 0.70 & 15 & 0.93 \\ 8 & 1.49 & \text { Mean } & 1.14\end{array}$

\section{Period of contact between virus and antiserum}

The interaction between virus and antiserum is not an immediate one, but requires time for its completion. Despite this well-known fact, there appears to be as great a difference of opinion on how long serum-virus mixtures should be allowed to interact as there is on the temperature at which this interaction should take place. Immediate inoculation has been practised by some workers (Rose \& Molloy, 1947); others have held the mixtures for $2 \mathrm{hr}$. (Blattner, Heys \& Gollub, 1943) or for varying periods of shorter duration before inoculation.

The progress of the reaction between virus and antiserum was therefore studied in the following series of experiments. Human serum, diluted $1 / 40$, was mixed with an equal volume of virus diluted to give a final concentration of about 600 P.F.U. $/ \mathrm{ml}$. Both reagents were prewarmed to $37^{\circ} \mathrm{C}$. and maintained at this temperature for the duration of each experiment. Samples of the mixture were removed at intervals and inoculated into eggs. The results of three such experiments are shown graphically in Fig. 1.

It is evident that equilibrium was reached between 1 and $2 \mathrm{hr}$., and that no further change took place in up to $6 \mathrm{hr}$. The relevant controls, in which serum was replaced by diluent, showed no significant change in titre over this period so that thermal inactivation could be excluded.

A series of similar experiments was performed with the same serum diluted 
1/160 and are recorded in Fig. 2. At this dilution equilibrium was not approached until 4-6 hr. had elapsed and reproducibility was much less evident. Both these latter findings probably reflect the decreased probability of effective contact between virus and antibody in dilute systems. Despite this evidence that neutralization in the high dilutions of antibody is not quite complete by $2 \mathrm{hr}$., it was decided to adopt this period as a standard time of incubation; this decision has proved satisfactory in practice. Incomplete neutralization would result in a tendency for the relevant mean pock counts to be too high, but no such tendency has in fact been found.

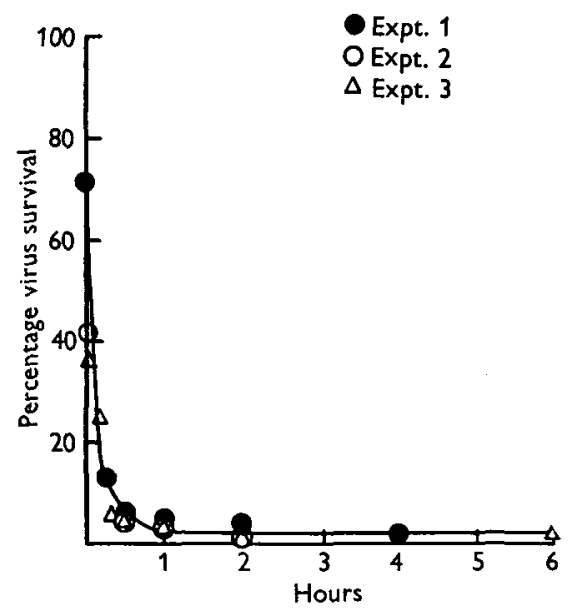

Fig. 1. Time-neutralization curve with human serum diluted $1 / 40$.

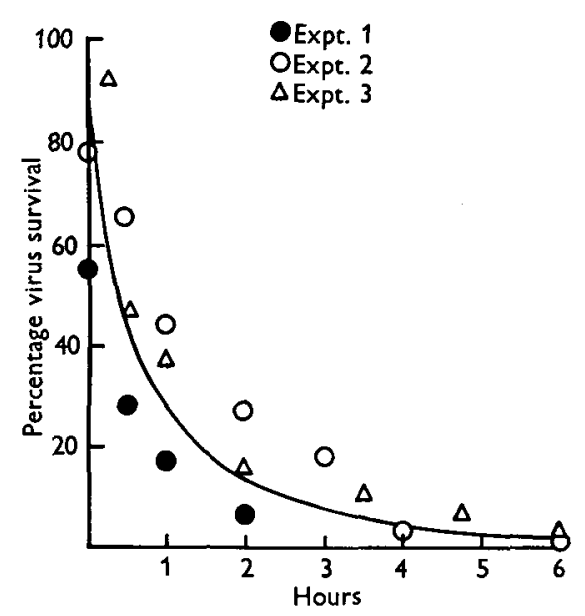

Fig. 2. Time-neutralization curve with human serum diluted $1 / 160$.

\section{Relationship between serum dilution and pock count}

The results of a typical experiment, in which serial dilutions of serum were incubated with a constant concentration of virus for $2 \mathrm{hr}$. at $37^{\circ} \mathrm{C}$., are shown in Figs. 3 and 4. The pock counts, expressed as percentages of the control count, have been plotted against serum dilutions on an arithmetical scale in Fig. 3 and on a logarithmic scale in Fig. 4; the serum dilutions are on a logarithmic scale in both cases.

It will be seen that the sigmoid curve of Fig. 3 is transformed to a straight line on the logarithmic plot. The sigmoid nature of the curve relating pock count to the corresponding serum dilution was pointed out by Keogh (1936). The linear transformation of such curves brought about by using logarithmic values is well known; it was used for illustrative purposes by Burnet, Keogh \& Lush (1937) in their monograph on neutralization and by Downie \& McCarthy (1950) as a means of comparing potencies of antisera in cross-neutralization experiments.

These results suggested that the dilution of serum containing an arbitrarily defined unit of antibody could be simply determined from a few experimental data. For the purposes of this paper the unit of antibody has been defined as that amount of antibody which will reduce a virus suspension to half its original titre. The titre 
of any antiserum may then be expressed as the reciprocal of the dilution containing one unit of antibody.

To determine whether the linear relationship held over a wide range, similar experiments were performed with high titre rabbit serum. The results of one such experiment are shown in Fig. 5. It is evident that linearity continues until a critical concentration of antibody is reached. From this point, a constant fraction of virus survives despite a 1000 -fold increase in antibody. Furthermore, the size of this surviving fraction is not only independent of antibody concentration but

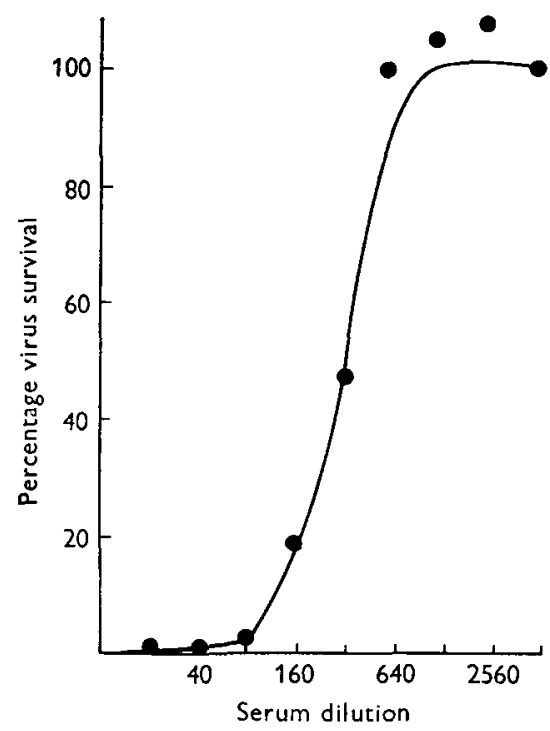

Fig. 3. Curve relating percentage survival of virus to serum dilution.

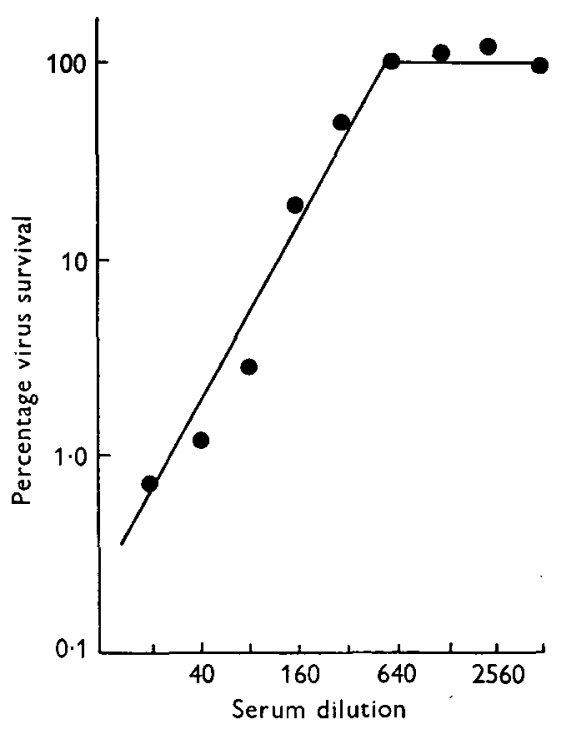

Fig. 4. Linear transformation on logarithmic scale.

of virus concentration as well. Thus, as is shown in Fig. 5, a tenfold increase in virus concentration with serum dilution $10^{-1}$ had little effect on the percentage survival of virus. Since the relationship is linear over the ranges at which a titration is carried out, even with high titre sera, this phenomenon does not interfere with the estimation of antibody titre.

\section{The slope of regression lines}

The slopes of regression lines representing various sera titrated on different days appeared to differ by experimental error only. Accordingly, a series of nine slopes, calculated by the method of least squares, from data obtained from sera of widely varying potencies, were tested statistically for parallelism. Although rigorous proof of this assumed parallelism is, of course, impossible, it was found that the assumption could not be refuted on the supplied data $(p>25 \%)$. From the same data a combined estimate of the true slope with its standard error gave a value of $0 \cdot 620 \pm 0 \cdot 048$. The regression equations, together with details of the sera from which they were obtained are given in Table 3 . 


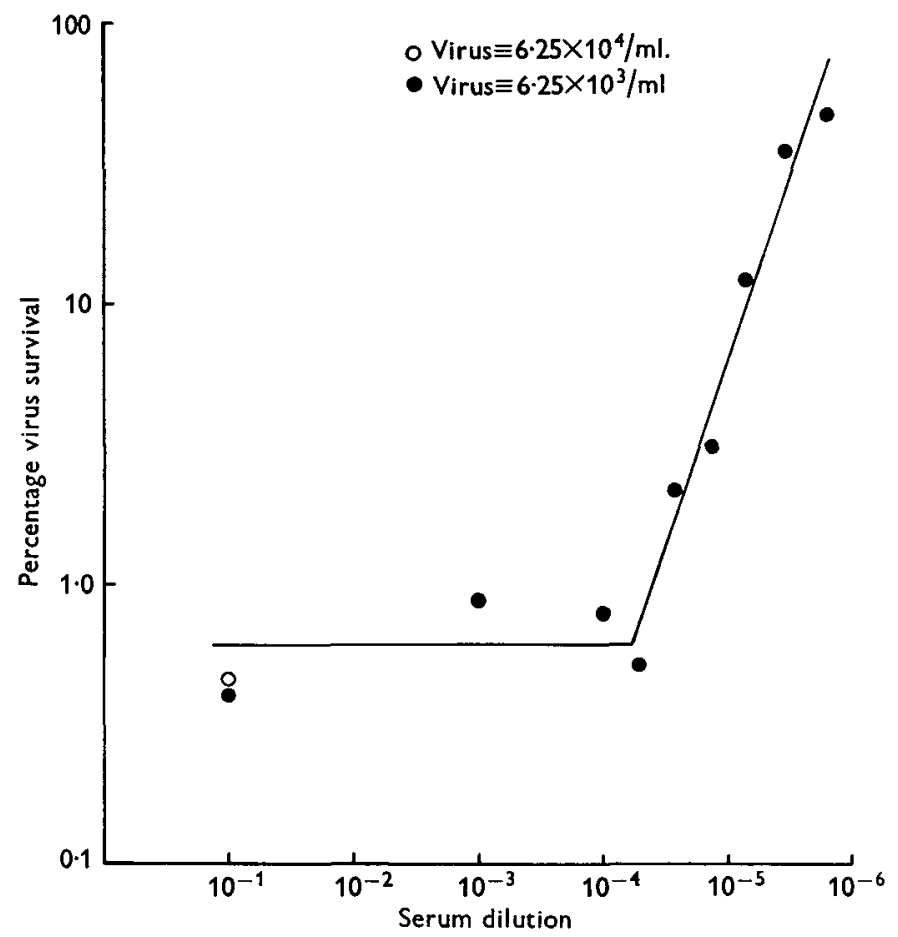

Fig. 5. The persistence of a constant fraction of unneutralized virus in the presence of excess antibody.

Table 3. Regression equations of various serum titrations

\begin{tabular}{|c|c|c|c|c|c|}
\hline \multirow[b]{2}{*}{ Expt. } & \multirow[b]{2}{*}{ Serum } & \multicolumn{2}{|c|}{ Equation values* } & \multirow[b]{2}{*}{ Titre† } & \multirow[b]{2}{*}{ Ratio } \\
\hline & & (b) & $(a)$ & & \\
\hline 1 & Human A & 0.62 & $1 \cdot 21 \pm 0.33$ & 145 & $4 \cdot 57$ \\
\hline 2 & Human A & 0.50 & $1.54 \pm 0.09$ & 240 & $1 \cdot 51$ \\
\hline 3 & Human A & $0 \cdot 61$ & $1 \cdot 33 \pm 0.32$ & 234 & 4.57 \\
\hline 4 & Human A & $0 \cdot 63$ & $1.50 \pm 0.21$ & 372 & $2 \cdot 63$ \\
\hline 5 & Human A & $0 \cdot 62$ & $1 \cdot 01 \pm 0.33$ & 347 & 4.57 \\
\hline 6 & Human B & $0 \cdot 54$ & $1.58 \pm 0.33$ & 316 & $\mathbf{4} \cdot 57$ \\
\hline 7 & Rabbit A & 0.66 & $2 \cdot 80 \pm 0.71$ & 8,128 & $26 \cdot 30$ \\
\hline 8 & Rabbit B & 0.48 & $2.94 \pm 0.19$ & 5,370 & $2 \cdot 40$ \\
\hline 9 & Rabbit C & 0.75 & $4 \cdot 44 \pm 0.30$ & 524,800 & 3.98 \\
\hline
\end{tabular}

* Values in equation $x=b y+a$ ( \pm fiducial limits of error), where $x=$ logarithm of serum dilution and $y=$ logarithm of mean pock count.

$\dagger$ Titre is reciprocal of dilution of serum calculated to reduce virus titre by $50 \%$.

$\ddagger$ Ratios of highest and lowest estimates of titre calculated from fiducial limits.

\section{The precision of the test}

The precision of any one titration, as determined by its fiducial limits of error, was found to vary. In Table 3 the ratios of the upper and lower estimates of the titres of various sera are given. These sera, differing widely in their potencies, were titrated on different days, using four serum dilutions for each titration. In general; 
it appears possible to distinguish between sera whose potencies vary by about fourfold. The greatest precision, in Expt. 2, gave a ratio of only $1 \cdot 5$.

To test the reproducibility of this type of antibody titration, a series of eleven replicate titrations of a human antiserum, and a further series of six titrations of a rabbit antiserum of greater potency were performed. For these titrations only three serum dilutions were used with only five eggs for each dilution. The results, given in Table 4, show the high degree of reproducibility that is possible, even under these economical conditions.

\section{Table 4. Replicate titrations of human and rabbit antisera}

\begin{tabular}{ccc} 
& \multicolumn{2}{c}{ Serum titres } \\
\cline { 2 - 3 } Titration & $\overbrace{\text { Human }}$ & Rabbit \\
1 & 197 & 5680 \\
2 & 174 & 6473 \\
3 & 121 & 4609 \\
4 & 147 & 4439 \\
5 & 208 & 4626 \\
6 & 224 & 6728 \\
7 & 121 & - \\
8 & 130 & - \\
9 & 149 & - \\
10 & 122 & - \\
11 & 132 & 5426 \\
Mean & 157 & 1.52 \\
Ratio* & 1.85 & \\
$*$ Ratio of highest and lowest values.
\end{tabular}

The titration of an unknown serum

As a result of the experiments reported above, the following procedure has been adopted in this laboratory for the titration of neutralizing antibody to the poxgroup of viruses.

Three serial tenfold dilutions of serum are mixed with equal volumes of virus, diluted to give a mean pock count of about seventy in the control mixture. Each mixture, after incubation, is inoculated into two eggs which are harvested $48 \mathrm{hr}$. later. From this pilot assay, which may be omitted if the probable titre of the serum is known, some idea is obtained of the dilutions of serum which will result in readable pock counts. Appropriate twofold serial dilutions of serum are then made and the test repeated, using about four serum dilutions and five eggs for each serum-virus mixture. Controls, consisting of virus mixed both with dilutions of a known positive serum and with diluent in place of serum, are included in each batch of tests.

Results, in the form of mean pock counts obtained with each serum dilution, are plotted on logarithmic graph paper; the straight line best fitting the data is then drawn by inspection and the serum titre read off. If preferred, the line can be calculated by the method of least squares, enabling fiducial limits to be applied to the result. 
As an example of the application of this method of measuring antibody, Fig. 6 shows the development of vaccinial antibody in an experimentally infected rabbit. The close approximation of the individual points to the straight line is further evidence of the good reproducibility attainable.

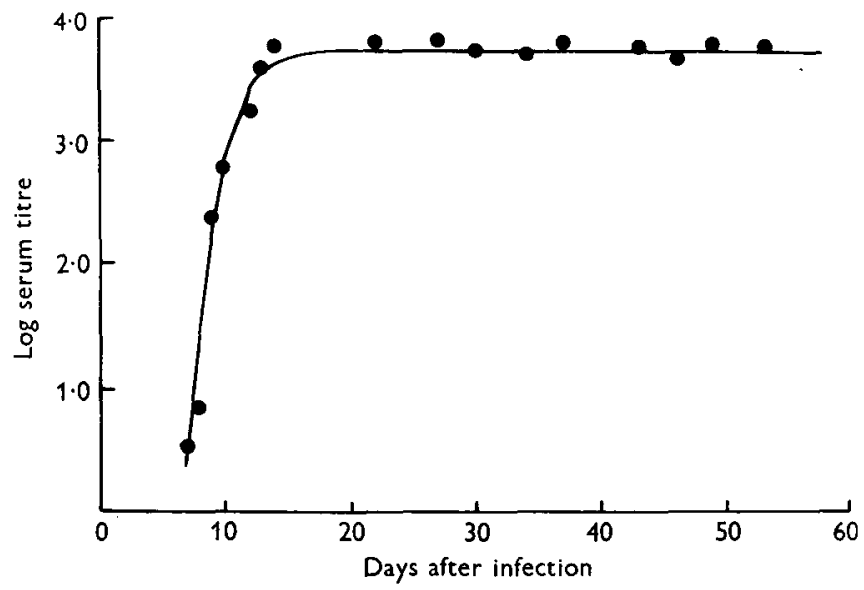

Fig. 6. The development of neutralizing antibody in a rabbit infected experimentally with vaccinia virus.

\section{DISCUSSION}

The experimental data have been fully discussed in the main body of the text, but one point of interest arising from these results warrants further consideration. It has been shown that there is a linear relationship between the logarithms of the antiserum dilution and of the percentage of vaccinia virus which remains infective when suspended in it. Although this agrees with a similar relationship established by Dulbecco et al. (1956) for the viruses of western equine encephalomyelitis and poliomyelitis, it contrasts sharply with the finding by Horsfall (1939) that influenzal antibody is related, in a similar logarithmic manner, not to the percentage of virus surviving, but directly to the amount of influenza virus neutralized. Subsequent workers have confirmed Horsfall's observation and have shown that it applies to many virus-host systems.

Whenever this latter type of relationship has been reported the virus has been titrated by a quantal response method, whereas in the work reported here, and in that of Dulbecco and his colleagues, a graded response method was used. It is unlikely, however, that different methods of titrating the virus will produce such a fundamental change in the serum-virus relationship. It is equally unlikely that the explanation lies in differences between viruses, because both types of relationship have been reported for the same virus, western equine encephalitis (Morgan, 1945; Dulbecco et al. 1956). Careful perusal of Horsfall's paper finally disclosed the reason for the discrepancy. What he, and subsequent workers, have plotted as ordinates is, not the logarithm of neutralized virus as claimed, but the reciprocal of the surviving virus. They have argued that if the $\mathrm{LD}_{50}$ titre of a virus suspension is reduced by antiserum from, say, $10^{-7}$ to $10^{-5}$, then $10^{2} \mathrm{LD}_{50}$ doses of virus have. 
been neutralized. In actual fact, as can be seen from column 5 , Table $5,10^{2} \mathrm{LD}_{50}$ doses have been reduced to $1 \mathrm{LD}_{50}$. This corresponds, not to $10^{2}$ doses neutralized, but to a survival of $1 / 10^{2}$. These authors have thus shown the same relationship as reported in this paper, except that they plotted the reciprocal of the surviving virus instead of the true figure, calling it 'amount of virus neutralized'.

Table 5. The relationship between the amount of virus added and that surviving in a hypothetical neutralization test in which the virus is titrated by a quantal response method

Virus dilution

Virus dose in $\mathrm{LD}_{50}$

Mortalities without antiserum (\%)

Mortalities with antiserum (\%)

Surviving virus in $\mathrm{LD}_{50}$

$\begin{array}{ccccccc}1 & 2 & 3 & 4 & 5 & 6 & 7 \\ 10^{-1} & 10^{-2} & 10^{-3} & 10^{-4} & 10^{-5} & 10^{-6} & 10^{-8} \\ 10^{6} & 10^{5} & 10^{4} & 10^{3} & 10^{2} & 10^{1} & 1 \\ 100 & 100 & 100 & 100 & 100 & 75 & 50 \\ 100 & 100 & 100 & 75 & 50 & 25 & - \\ - & - & - & - & 1 & - & -\end{array}$

The relationships of the serum dilution to the neutralized virus, the surviving virus and to the reciprocal of the surviving virus, are all illustrated in Fig. 7. The data from which this figure was constructed have been calculated from Textfigure 3 of Horsfall's paper. It shows that plotting the neutralized virus as ordinate

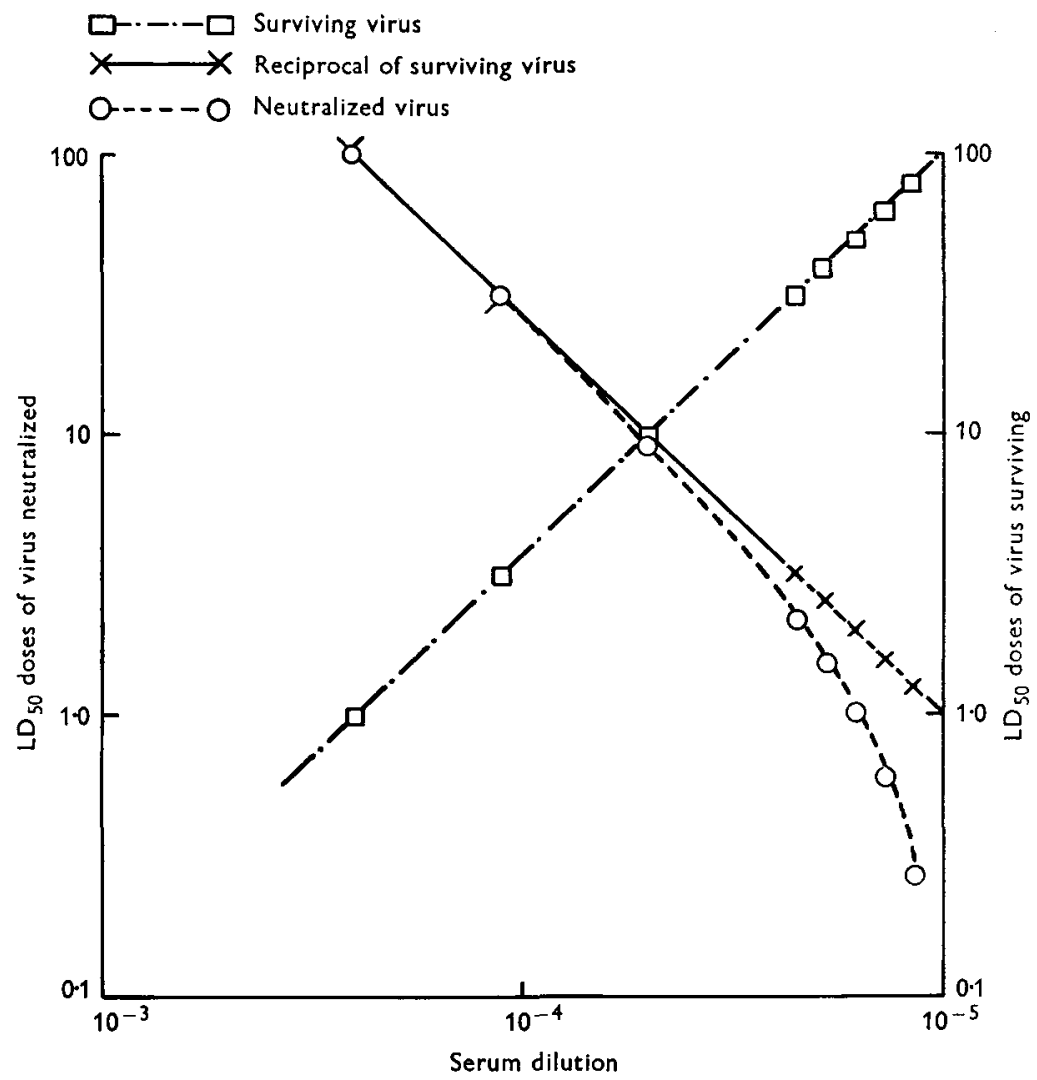

Fig. 7. To show the relationship of serum dilution to the neutralized virus, the surviving virus and to the reciprocal of the surviving virus. 
results in a curve asymptotic to the straight line obtained by plotting the reciprocal of the virus survival. This latter line has the same slope but the opposite direction to that obtained by plotting the actual virus survival.

\section{SUMMARY}

A study has been made of various factors involved in performing neutralization tests with vaccinia virus on chorio-allantoic membranes.

The common practice of using a single serum concentration has been shown to result in a test which is qualitative only. The linear relationship between the logarithm of the pock count of the surviving virus and the logarithm of the serum dilution can be used to determine the dilution of serum which will neutralize $50 \%$ of a virus suspension. By this method it is possible to distinguish between sera whose potencies vary by about fourfold.

I gratefully acknowledge the advice and criticism given by Dr J. C. N. Westwood and Dr I. A. Macpherson, as well as the help given by Mr S. Peto with the statistical treatment of results. My thanks are also due to Mr H. B. Maber and Corporal M. Fitzpatrick, R.A.M.C., for their technical assistance.

\section{REFERENCES}

Blattner, R. J., Heys, F. M. \& Gollub, S. W. (1943). Antibody-response to cutaneous inoculation with vaccinial virus in human subjects, utilising the egg-protection technic. I. Serum-virus neutralisation. J. Immunol. 46, 207.

Briody, B. A., Ledinko, N. \& Stannard, C. (1951). Studies on vaccinia virus. II. Neutralisation of vaccinia virus by normal guinea pig serum. J. Immunol. 67, 413.

Burnet, F. M. \& Lush, D. (1939). Herpes simplex. Studies on the antibody content of human sera. Lancet, i, 629.

Burnet, F. M., KEogh, E. V. \& Lush, D. (1937). The immunological reactions of the filterable viruses. Aust. J. exp. Biol. med. Sci. 15, 231.

DownIE, A. W. \& MCCARTHY, K .(1950). The viruses of variola, vaccinia, cowpox, and ectromelia. Neutralisation tests on the chorio-allantois with unabsorbed and absorbed sera. Brit. J. exp. Path. 31, 789.

Dulbecco, R., Vogt, M. \& Strickland, A. G. R. (1956). A study of the basic aspects of neutralisation of two animal viruses, western equine encephalitis and poliomyelitis. Virology, 2, 162.

Horsfalt, F. L. Jr. (1939). Neutralization of epidemic influenza virus. J. exp. Med. 70, 209.

Jawetz, E. \& Coleman, V. R. (1952). Studies on herpes simplex virus. III. The neutralisation of egg-adapted herpes virus by human sera in ovo. J. Immunol. 68, 645.

KEOGH, E. V. (1936). Titration of vaccinia virus on the chorio-allantoic membrane of the chick embryo and its application to immunological studies of neuro-vaccinia. J.Path. Bact. 43, 441.

MorgaN, I. M. (1945). Quantitative study of the neutralisation of western equine encephalomyelitis virus by its antiserum and the effect of complement. J. Immunol. 50, 359.

Parker, R. F. (1939). The neutralisation of vaccinia virus by serum of vaccinia-immune animals. J. Immunol. 36, 147.

Rose, H. M. \& Molloy, E. (1947). Cutaneous reactions with the virus of herpes simplex. J. Immunol. 56, 287.

Sternberg, G. M. (1892). Practical results of bacteriological researches. Trans. Ass. Amer. Phycns, 7, 68.

Westwood, J. C. N., Phipps, P. H. \& Boulter, E. A. (1957). The titration of vaccinia virus on the chorio-allantoic membrane of the developing chick embryo. J. Hyg., Camb., $\mathbf{5 5}$, 123.

(MS. received for publication 11. III. 57) 